\title{
Interaction of water components in the semi-arid Huasco and Limarí river basins, North Central Chile
}

\author{
G. Strauch ${ }^{1}$, R. Oyarzún ${ }^{2,3}$, F. Reinstorf ${ }^{4}$, J. Oyarzún ${ }^{2}$, M. Schirmer ${ }^{5}$, and K. Knöller ${ }^{6}$ \\ ${ }^{1}$ Helmholtz Centre for Environmental Research UFZ, Department Hydrogeology, Permoserstrasse 15, \\ 04318 Leipzig, Germany \\ ${ }^{2}$ Departamento Ingeniería de Minas, Universidad de La Serena, Casilla 554, La Serena, Chile \\ ${ }^{3}$ Centro de Estudios Avanzados en Zonas Aridas (CEAZA), Benavente 980, La Serena, Chile \\ ${ }^{4}$ Technical University Magdeburg-Stendal, Department Water Management, Breitscheidstraße 2, 39114 Magdeburg, Germany \\ ${ }^{5}$ EAWAG - Swiss Federal Institute of Aquatic Science and Technology, Department Water Resources and Drinking Water, \\ Dübendorf, Switzerland \\ ${ }^{6}$ Helmholtz Centre for Environmental Research UFZ, Department Isotope Hydrology, Theodor-Lieser-Str. 4, \\ 06120 Halle (Saale), Germany
}

Received: 15 May 2009 - Revised: 12 June 2009 - Accepted: 17 June 2009 - Published: 13 October 2009

\begin{abstract}
For sustainable water resource management in semi-arid regions, sound information is required about interactions between the different components of the water system: rain/snow precipitation, surface/subsurface run-off, groundwater recharge. Exemplarily, the Huasco and Limarí river basins as water stressed river catchments have been studied by isotope and hydrochemical methods for (i) the origin of water, (ii) water quality, (iii) relations of surface and groundwater.

Applying the complex multi-isotopic and hydrochemical methodology to the water components of the Huasco and Limarí basins, a differentiation of water components concerning subsurface flow and river water along the catchment area and by anthropogenic impacts are detected. Sulphate and nitrate concentrations indicate remarkable input from mining and agricultural activities along the river catchment.

The ${ }^{2} \mathrm{H}-{ }^{18} \mathrm{O}$ relations of river water and groundwater of both catchments point to the behaviour of river waters originated in an arid to semi-arid environment.

Consequently, the groundwater from several production wells in the lower parts of the catchments is related to the rivers where the wells located, however, it can be distinguished from the river water. Using the hydrological wa-
\end{abstract}

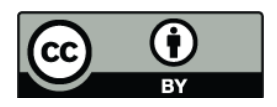

Correspondence to: G. Strauch (gerhard.strauch@ufz.de) ter balance and the isotope mixing model, the interaction between surface and subsurface flows and river flow is estimated.

\section{Introduction}

In the Coquimbo and Atacama regions the vulnerability of the natural water resources is increasing by the water requirements of the agricultural and mining industry and of the urban development which requires a sustainable water resource management. An increasing demand of sound information about the origin of water resources, their quality, the groundwater recharge conditions, surface and subsurface run-off, rain/snow precipitation and water use is required for a proper management of water resources. A water quality data base was established for several important catchment areas in semi-arid zones by the CADE-IDEPE in 2004 (CADE-IDEPE, 2004a, b). These data were evaluated according to sustainable water resource management by Ribbe et al. (2008) due to the water quality and monitoring practice for requirements of water policy and legislative measures. Because of increasing demand of water for agriculture, mining, and domestic use, groundwater abstraction gains importance in river catchments, but needs a better understanding about its interaction with surface water in semi-arid watersheds. Groundwater resources in two relevant

Published by Copernicus Publications on behalf of the European Geosciences Union. 
and water stressed river catchments of the Atacama and Coquimbo Regions - the Huasco and Limarí river basins - are associated to shallow sediments of the flood plains in direct interaction with the river surface discharge, and to fractured rock aquifers (Rojas et al., 2008). The groundwater source is currently used in small proportion for domestic consumption and irrigation purposes by local suppliers. According to a study at the Elqui basin using combined multi-isotope and hydrochemical methods, the groundwater dynamic to the river basin and its origin from the fractured basement could be estimated (Strauch et al., 2006).

Applying this methodology exemplarily to the catchments of the Huasco and Limarí basins, we aimed on an improved understanding about the origin of water components, water quality, and the interaction of surface and groundwater in those catchments.

\section{Geological settings, sampling and analytics}

The geology of the both watersheds is characterized by a variety of rock units ranging in age from Palaeozoic to Quaternary whereas the high-altitude domain of the region comprises a volcanic series of the Doña Ana Formation (Upper Oligocene-Lower Miocene) with important metallogenic provinces (Maksaev et al., 1984; Bissig et al., 2002).

Groundwater in the Huasco and Limarí catchment is present in (i) a gravel-sand dominated aquifer formed by shallow sediments of the flood plains of valleys and gulches, and in (ii) fractured rock aquifers corresponding to both granitic batholiths and volcanic and sedimentary beds (Rojas et al., 2008). The shallow aquifer is influenced by the high run-off dynamic of the rivers during either direct precipitation or snow melting in the Andes. Run-off data between 0.79 and $2.14 \mathrm{~m}^{3} \mathrm{~s}^{-1}$ for the Huasco river (at Algodones, DGA station), and for the Limarí catchment Rio Grande (at Puntilla San Juan) between 3.75 and $5.62 \mathrm{~m}^{3} \mathrm{~s}^{-1}$ and the Rio Limarí (at Ovalle, Panamericana) with 1.07 and $1.73 \mathrm{~m}^{3} \mathrm{~s}^{-1}$ point to the remarkable dynamic of the watershed (Table 1; DGA data).

Less important due to the amount of water, the fractured rock aquifer discharges in natural springs in the mountains and used on a small scale for domestic consumption and irrigation purposes by local farmers.

Sampling was performed at the end of austral spring in November 2006, localities and relevant features are displayed in Table 2 and Fig. 1. Surface water sampling was scooped from different tributaries of the catchments starting at altitudes of $1890 \mathrm{~m}$ a.s.l. along the river courses down to the main cities of the catchments Vallenar and Ovalle, respectively (Fig. 1).

Groundwater was sampled from operating wells of the local water suppliers in Vallenar, Ovalle, and Monte Patria. Hydrochemical parameters as $\mathrm{pH}$ and electric conductivity (EC) were directly measured during sampling, alkalinity was
Table 1. Run-off data from the catchment areas investigated at DGA-Stations in November 2006 (DGA, 2007).

\begin{tabular}{|c|c|c|c|c|c|}
\hline \multirow[t]{2}{*}{ Catchment } & \multirow[t]{2}{*}{ Station } & \multirow[t]{2}{*}{ Lat/Long } & \multicolumn{3}{|c|}{ Flow $\left(\mathrm{m}^{3} \mathrm{~s}^{-1}\right)$} \\
\hline & & & Mean & Min & Max \\
\hline Rio Huasco & $\begin{array}{l}\text { Algodones } \\
3820001\end{array}$ & $28.44 / 70.33$ & 1.263 & 0.788 & 2.141 \\
\hline $\begin{array}{l}\text { Rio Limarí/ } \\
\text { Rio Hurtado }\end{array}$ & $\begin{array}{l}\text { Samo Alto } \\
\text { (Ang) }\end{array}$ & & 1.14 & 0.73 & 1.77 \\
\hline $\begin{array}{l}\text { Rio Limarí/ } \\
\text { Rio Grande }\end{array}$ & $\begin{array}{l}\text { Puntilla San } \\
\text { Juan } 4523002\end{array}$ & $30.42 / 70.55$ & 5.62 & 3.75 & 7.02 \\
\hline Rio Limarí & Panamericana & & 1.36 & 1.07 & 1.73 \\
\hline
\end{tabular}

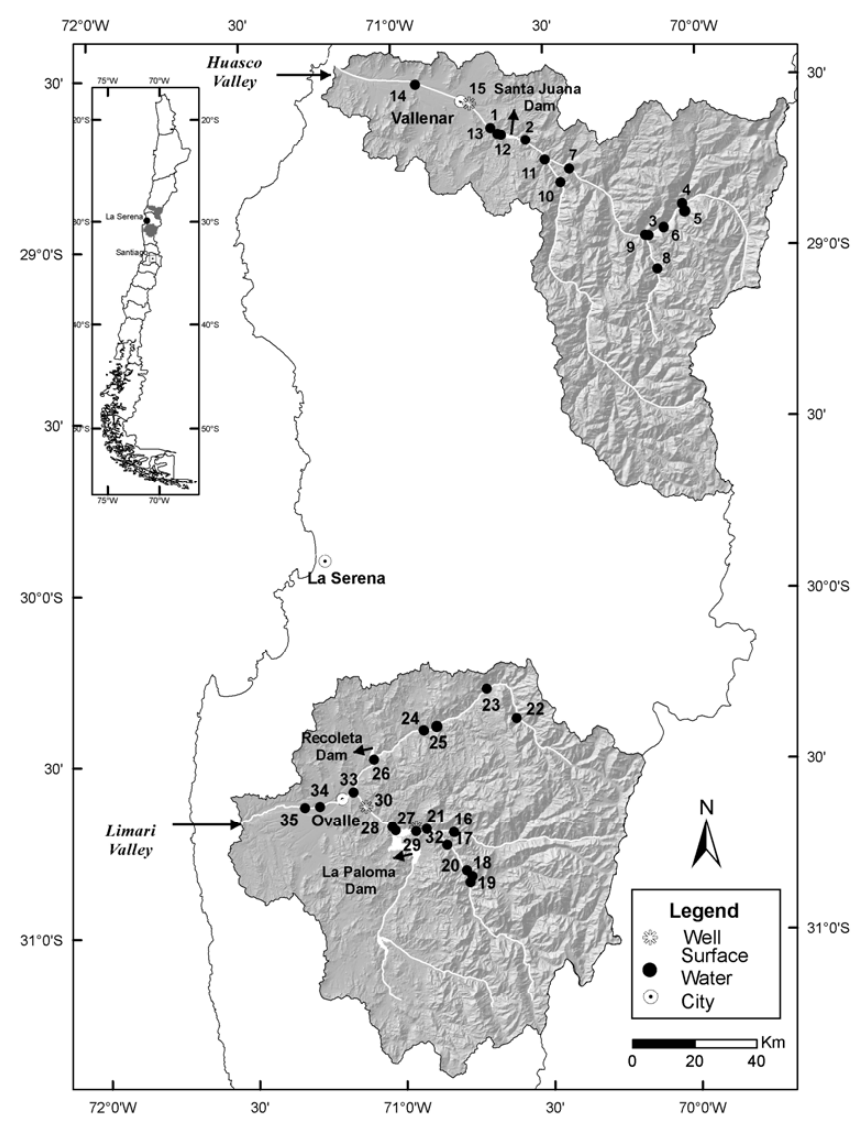

Fig. 1. Investigation areas and sampling locations in the catchments of Rio Huasco (above) and Rio Limarí (below).

titrated in the field. Samples for hydrochemical analysis were filtered with $0.45 \mu \mathrm{m}$ cellulose acetate filters. Anions were analysed using the ion chromatograph system D120 from Dionex with a reproducibility of $5 \%$ for each anion. Major cations were performed by ICP-AES (Varian) with an accuracy of $5 \%$.

$\mathrm{H}$ - and O-isotopes were on-line measured by the XLPlus Continuous flow IRMS (Thermo Electron Corporation) 
Table 2. Sampling location characteristics, hydrochemical and isotope data including water flux estimations during sampling. The sampling was from 11 to 15 November, 2006.

\begin{tabular}{|c|c|c|c|c|c|c|c|c|c|c|c|c|c|c|c|c|c|}
\hline \multirow[b]{2}{*}{$\mathrm{Nr}$} & \multicolumn{2}{|l|}{ Sampling locations } & \multicolumn{3}{|c|}{ Hydrological parameter } & \multirow[b]{2}{*}{$\mathrm{Na}^{+}$} & \multirow[b]{2}{*}{$\mathrm{K}^{+}$} & \multirow[b]{2}{*}{$\mathrm{Mg}^{++}$} & \multicolumn{3}{|c|}{ Hydrochemistry } & \multirow[b]{2}{*}{$\mathrm{HCO}_{3}^{-}$} & \multirow[b]{2}{*}{$\mathrm{NO}_{3}^{-}$} & \multirow{2}{*}{$\begin{array}{r}\text { Water flux } \\
\mathrm{Q} \\
\mathrm{m}^{3} \mathrm{~s}^{-1}\end{array}$} & \multicolumn{3}{|c|}{ Stable isotopes } \\
\hline & Location & $\begin{array}{c}\text { Altitude } \\
\text { ma.s.l. }\end{array}$ & $\begin{array}{r}\mathrm{T} \\
{ }^{\circ} \mathrm{C}\end{array}$ & $\begin{array}{l}\text { el. Cond. } \\
\mu \mathrm{S} \mathrm{cm}^{-1}\end{array}$ & $\mathrm{pH}$ & & & & $\mathrm{Ca}^{++}$ & $\mathrm{Cl}^{-}$ & $\mathrm{SO}_{4}^{--}$ & & & & $\delta^{18} \mathrm{O}$ & $\begin{array}{l}\delta^{2} \mathrm{H} \\
\mathrm{o} / \mathrm{oo}\end{array}$ & d-excess \\
\hline & $\begin{array}{l}\text { Catchment Huasco: Rio } \\
\text { Huasco/Tránsito/Carmen, }\end{array}$ & & & & & & & & & & & & & & & & \\
\hline 8 & Pascua Lama gate door & 1888 & 15.8 & 382 & 8.18 & 6.7 & 0.9 & 10.7 & 51.4 & 2.0 & 132.6 & 93 & 1.71 & 0.77 & -13.59 & -98.7 & 10.0 \\
\hline 4 & Caceo village & 1859 & 18.6 & 315 & 9.18 & 17.2 & 1.6 & 6.5 & 38.3 & 6.1 & 45.1 & 121 & 0.61 & 0.106 & -10.47 & -83.8 & 0.0 \\
\hline 5 & Valeriano Bridge & 1827 & 17.3 & 573 & 8.29 & 22.8 & 1.6 & 11.7 & 72.1 & 18.7 & 190.3 & 66 & 2.04 & 1.54 & -13.25 & -99.7 & 6.3 \\
\hline 3 & Conay Bridge & 1384 & 21.6 & 497 & 8.14 & 8.6 & 1.4 & 12.0 & 71.4 & 2.8 & 182.0 & 41 & 1.00 & 1.8 & -13.10 & -96.7 & 8.1 \\
\hline 9 & after conflue Conay & 1436 & 23.1 & 537 & 8.03 & 15.6 & 1.4 & 11.7 & 75.2 & 8.9 & 179.6 & 72 & 1.13 & 2.16 & -12.97 & -96.2 & 7.5 \\
\hline 6 & Malaguin Bridge & 1198 & 17.5 & 545 & 8.44 & 22.3 & 1.6 & 10.9 & 70.2 & 16.7 & 164.0 & 79 & 1.77 & 1.18 & -12.72 & -96.6 & 5.2 \\
\hline 7 & Puente Negra & 864 & 19.3 & 722 & 8.68 & 30.7 & 2.1 & 16.2 & 99.0 & 14.7 & 196.0 & 160 & 2.30 & 2.25 & -11.99 & -91.6 & 4.2 \\
\hline 10 & Retamo Village & 902 & 19.2 & 792 & 8.60 & 23.3 & 2.0 & 20.4 & 116.0 & 8.3 & 265.2 & 157 & 1.77 & 0.93 & -13.20 & -100.7 & 4.9 \\
\hline 11 & $\begin{array}{l}\text { Conflue after Alto d } \\
\text { Carmen, near Algodones }\end{array}$ & 790 & 23.8 & 766 & 8.43 & 28.3 & 2.3 & 19.3 & 105.2 & 12.8 & 251.4 & 137 & 1.41 & 1.8 & -12.25 & -94.4 & 3.6 \\
\hline 2 & St Juana Dam inflow & 643 & 22.9 & 778 & 8.54 & 27.0 & 2.2 & 19.0 & 107.6 & 12.5 & 239.3 & 152 & 1.67 & 2.3 & -12.36 & -95.2 & 3.7 \\
\hline 12 & Surface St Juana Dam & 650 & 20.9 & 644 & 8.60 & 23.3 & 1.8 & 16.2 & 86.7 & 11.0 & 211.4 & 102 & 0.76 & n.e. & -11.59 & -90.0 & 2.8 \\
\hline 13 & St Juana Dam outflow & 618 & 15.7 & 649 & 8.50 & 22.8 & 1.8 & 15.7 & 90.1 & 18.3 & 209.2 & 117 & 1.18 & n.e. & -11.98 & -92.2 & 3.6 \\
\hline 1 & Vallenar, upstream & 448 & 17.0 & 652 & 8.62 & 22.0 & 1.7 & 15.4 & 87.8 & 13.0 & 204.8 & 115 & 1.11 & n.e. & -11.91 & -91.9 & 3.3 \\
\hline 14 & $\begin{array}{l}\text { Rio Huasco, } \\
\text { downstream Val }\end{array}$ & 242 & 16.1 & 2040 & 8.66 & 247.8 & 4.9 & 38.9 & 201.0 & 198.5 & 586.9 & 331 & 6.17 & 10 & -10.96 & -85.7 & 2.0 \\
\hline 18 & $\begin{array}{l}\text { Catchment Limarí: } \\
\text { Rio Grande } \\
\text { vill. Carén, } \\
\text { Pte Mostazal }\end{array}$ & 703 & 19.6 & 410 & 8.34 & 12.1 & 1.1 & 9.5 & 62.0 & 4.5 & 64.1 & 173 & 1.73 & 1.4 & -11.88 & -87.2 & 7.9 \\
\hline 19 & vill. Carén & 700 & 18.7 & 186 & 8.40 & 7.1 & 0.6 & 2.7 & 26.6 & 4.7 & 16.6 & 82 & 0.25 & 6.8 & -12.43 & -89.6 & 9.8 \\
\hline 20 & Semita Bridge & 674 & 18.1 & 221 & 8 & 7.9 & 0 & & & 4 & & 93 & & 6.8 & & & 9.6 \\
\hline 16 & Rio Rapel & 619 & 19.9 & 535 & 8.25 & 17.4 & 1 & 13.8 & 78.5 & 4.3 & 73.9 & 244 & & 0.23 & -11.86 & -87.1 & 7.8 \\
\hline 17 & $\begin{array}{l}\text { vill. Chilecito, } \\
\text { Pte Mialqui }\end{array}$ & 516 & 20.9 & 235 & 9.11 & 8.4 & 0.7 & 4.0 & 33.8 & 5.1 & 24.3 & 35 & 0.24 & 6.17 & -12.24 & -88.9 & 9.0 \\
\hline 21 & $\begin{array}{l}\text { Rio Grande, before } \\
\text { La Paloma Dam }\end{array}$ & 444 & 20.3 & 287 & 8.31 & 10.7 & 0.8 & 5.8 & 41.2 & 5.8 & 30.4 & 127 & 0.50 & 5.6 & -12.00 & -87.3 & 8.7 \\
\hline 27 & $\begin{array}{l}\text { Rio Grande, direct input } \\
\text { La Paloma Dam, Pte Patria }\end{array}$ & 383 & 19.9 & 318 & 7.64 & 12.3 & 1.0 & 6.7 & 48.5 & 12.9 & 31.4 & 162 & 0.11 & 7.6 & -11.91 & -86.8 & 8.4 \\
\hline 28 & $\begin{array}{l}\text { La Paloma Dam, } \\
\text { surface water }\end{array}$ & 386 & 19.4 & 305 & 8.81 & 14.5 & 1.5 & 7.7 & 39.4 & 7.3 & 38.1 & 131 & 0.35 & n.e. & -8.71 & -67.9 & 1.7 \\
\hline 29 & Outlet La Paloma Dam & 305 & 16.1 & 318 & 8.33 & 15.0 & 1.5 & 8.0 & 41.1 & 7.3 & 38.0 & 134 & 0.51 & 2.9 & -8.87 & -68.8 & 2.2 \\
\hline & $\begin{array}{l}\text { Catchment Limarí: } \\
\text { Rio Hurtado }\end{array}$ & & & & & & & & & & & & & & & & \\
\hline 22 & $\begin{array}{l}\text { Rio Hurtado, } \\
\text { Las Breas }\end{array}$ & 1540 & 13.3 & 263 & 8.31 & 6.6 & 1.0 & 4.5 & 36.8 & 3.5 & 74.3 & 48 & 1.01 & 3.2 & -13.73 & -100.8 & 9.1 \\
\hline 23 & $\begin{array}{l}\text { downst Hurtado, upstr } \\
\text { Fundina, Puente }\end{array}$ & 1531 & 16.3 & 345 & 8.33 & 10.7 & 1.3 & 7.4 & 49.1 & 4.4 & 79.1 & 97 & 1.68 & n.e. & -13.44 & -98.9 & 8.6 \\
\hline 24 & $\begin{array}{l}\text { Samo Alto, Pte } \\
\text { Samo Alto }\end{array}$ & 606 & 22.7 & 446 & 8.90 & 15.2 & 1.2 & 9.4 & 68.1 & 6.4 & 90.6 & 163 & 0.55 & 1.8 & -13.01 & -96.7 & 7.3 \\
\hline 26 & $\begin{array}{l}\text { Recoleta Dam, } \\
\text { surface water }\end{array}$ & 421 & 21.0 & 436 & 8.72 & 16.9 & 1.7 & 10.0 & 62.7 & 8.6 & 92.3 & 146 & 0.17 & n.e. & -10.02 & -79.3 & 0.9 \\
\hline & $\begin{array}{l}\text { Catchment Limarí: } \\
\text { Rio Limarí }\end{array}$ & & & & & & & & & & & & & & & & \\
\hline 34 & $\begin{array}{l}\text { Rio El Ingenio, } \\
\text { tribut. Rio Limari }\end{array}$ & 177 & 25.3 & 3370 & 8.44 & 344.8 & 5.8 & 153.2 & 289.9 & 811.6 & 630.9 & 277 & 14.55 & n.e. & -7.42 & -59.6 & -0.3 \\
\hline 33 & $\begin{array}{l}\text { Rio Grande, input } \\
\text { Los Peniones, Ovalle }\end{array}$ & 374 & 21.5 & 464 & 9.00 & 33.2 & 1.8 & 12.5 & 52.9 & 19.5 & 54.9 & 194 & 0.20 & n.e. & -8.24 & -65.1 & 0.8 \\
\hline 35 & $\begin{array}{l}\text { Rio Limari, } \\
\text { vill Trapiche }\end{array}$ & 115 & 24.5 & 1045 & 9.52 & 111.3 & 3.1 & 21.7 & 94.0 & 121.4 & 112.5 & 293 & 3.16 & n.e. & -7.59 & -60.9 & -0.2 \\
\hline & Groundwater & & & & & & & & & & & & & & & & \\
\hline 15 & Waterworks Vallenar & 259 & 19.6 & 895 & 7.70 & 87.8 & 3.6 & 16.7 & 76.7 & 42.0 & 204.9 & 226 & 8.51 & n.e. & -11.80 & -90.1 & 4.3 \\
\hline 30 & $\begin{array}{l}\text { Well Ovalle, Aguas } \\
\text { del Valle Ovalle }\end{array}$ & 277 & 18.5 & 641 & 7.07 & 50.2 & 1.7 & 17.2 & 65.6 & 29.1 & 62.9 & 268 & 15.09 & n.e. & -8.50 & -65.2 & 2.8 \\
\hline 32 & $\begin{array}{l}\text { Well Monte Patria, Aguas } \\
\text { del Valle Ovalle }\end{array}$ & 401 & 19.3 & 631 & 7.09 & 39.6 & 1.5 & 14.8 & 79.3 & 15.0 & 71.4 & 273 & 14.90 & n.e. & -10.63 & -78.8 & 6.2 \\
\hline
\end{tabular}

n.e.=not estimated; No. 25 not sampled. 


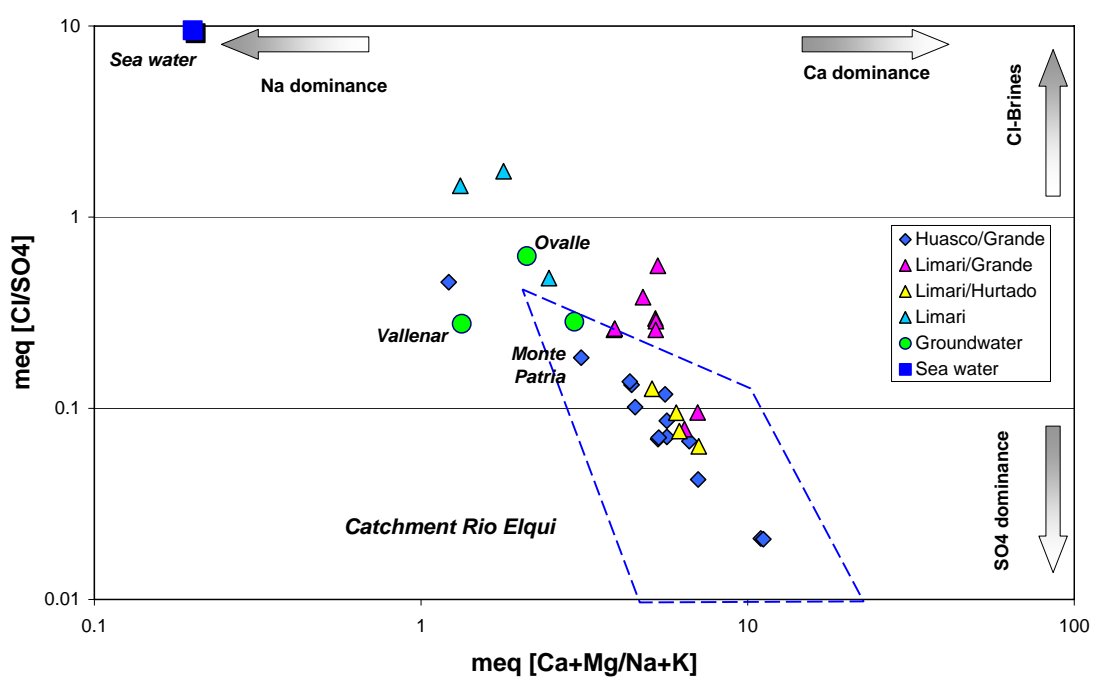

Fig. 2. Hydrochemical characteristics of river and groundwater from the Rio Huasco and Rio Limarí catchments in relation to the Rio Elqui catchment (dotted area).

(Gehre and Strauch, 2004). Isotope ratios of hydrogen and oxygen are reported in the $\delta$-notation

$\delta=\left(\left[R_{\text {sample }} / R_{\text {standard }}\right]-1\right) * 1000$,

with values expressed in \%o vs. VSMOW (Vienna Standard Mean Ocean Water) with $R=\left[{ }^{18} \mathrm{O} /{ }^{16} \mathrm{O}\right]$ and $\left[{ }^{2} \mathrm{H} / \mathrm{H}\right]$, respectively. The accuracy of the isotope analysis is $0.8 \%$ o for hydrogen and $0.1 \%$ o for oxygen. All analyses were performed at the laboratories of the UFZ-Departments Hydrogeology and Isotope Hydrology in Halle/Saale, Germany.

Table 2 presents the data of the field measurements and the hydrochemical an isotope analyses.

\section{Results and discussion}

\subsection{Hydrochemistry}

The river waters from the Huasco watersheds, the northern and more arid area, are generally characterized by increasing mineralization along the tributaries Rio Conay/Chollay, Rio El Tránsito, Rio Del Carmen downstream to the Rio Huasco. The surface water for the Huasco watershed is $\mathrm{Ca}-, \mathrm{Na}-$ and sulphate stressed resulting in a $\mathrm{Ca}-(\mathrm{Na})-\mathrm{SO}_{4}-\left(\mathrm{HCO}_{3}\right)$ water type. Downstream of Vallenar (14), the highest load of mineralization was analysed including nitrate which reflects clearly the agricultural and urban input of the Vallenar area. River water from the Rio Chollay (samples 3,8 ) has a remarkable load of sulphate (Fig. 2) discharging the high mountain mining area (Pascua Lama District). Similar ion ratios were observed in the upper part of the Elqui catchment influenced by gold-copper mining (Strauch et al., 2006).

Along the Limarí watershed, located more in a semi-arid environment, river water is less mineralized than that of the
Huasco catchment: it concerns the main tributaries Rio Hurtado and Rio Grande. Downstream Ovalle at Trapiche, a significant urban and agricultural impact can be observed, and is evidently in the high mineralized stream water of the El Ingenio with particularly high nitrate concentration. Generally, the water type of the mountain controlled Limarí watershed upstream Ovalle is $\mathrm{Na}-(\mathrm{Ca})-\mathrm{HCO}_{3}-\mathrm{SO}_{4}$.

Groundwater, the second important water resource in the catchments, confirms its origin from the catchment runoff (Fig. 2), but is affected by anthropogenic activities. In Vallenar, the groundwater signature follows the Huasco river water type, but changes its character to $\mathrm{Na}-\mathrm{Ca}-\mathrm{SO}_{4}-$ $\left(\mathrm{HCO}_{3}\right)$ similarly to the polluted river water downstream Vallenar (14). The groundwater in the important agricultural region of Monte Patria (Limarí catchment) is of Ca(Na)- $-\mathrm{HCO}_{3}-\left(\mathrm{SO}_{4}\right)$ type. The abstracted groundwater (32) is consequently nitrate polluted in relation to the receiving water in this part of the Limar catchment. Interaction of surface (river, La Paloma reservoir) and subterranean water (bank filtration, groundwater) can influence the type of groundwater near Monte Patria (Figs. 2, 3, Table 2). Downwards near Ovalle, river water (33) and groundwater (30) have the same $\mathrm{Ca}-(\mathrm{Na})-\mathrm{HCO}_{3}-\left(\mathrm{SO}_{4}\right)$ water signature, but anthropogenic based with likewise high nitrate concentration in the groundwater.

\subsection{Stable isotopes of water}

As reported above, river and groundwater in both watersheds correlate in their hydrochemical signature. Anthropogenic pollutants, however, can influence the water types and thus the clear distinction between the origins of the water components. That's why the application of stable water isotopes 


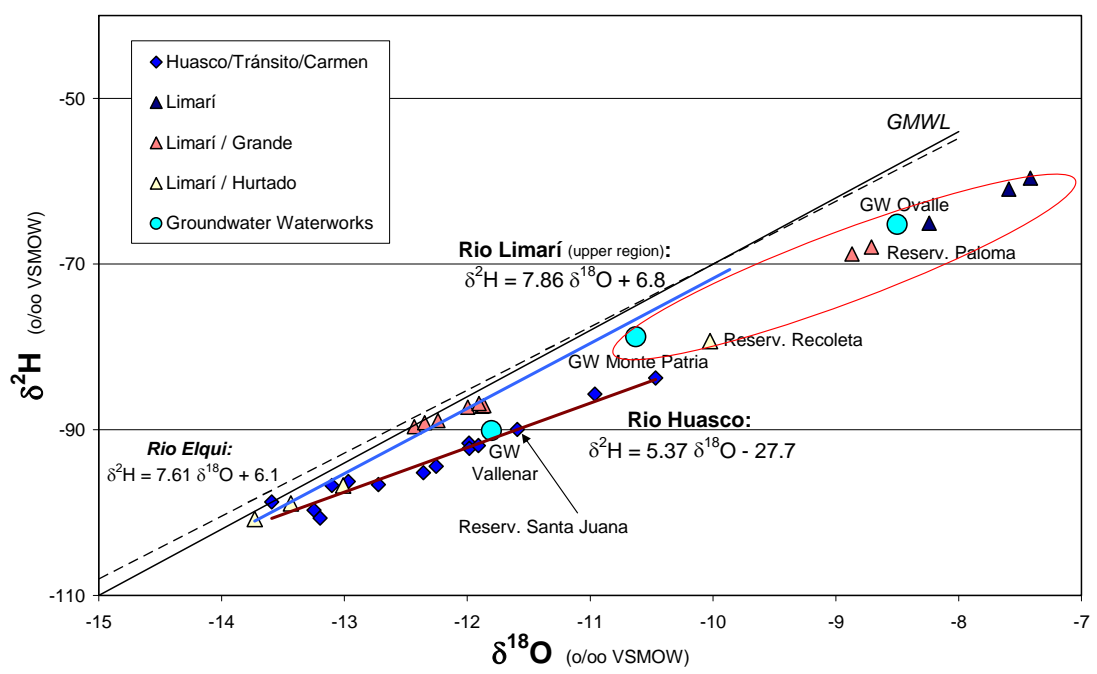

Fig. 3. Isotopic signature of the water components of the both catchments within the $\delta^{2} \mathrm{H}-\delta^{18} \mathrm{O}$ diagram. The water line of the Huasco catchment comprises all tributaries. For the Limarí catchment, only run-off of the mountain tributaries forms the water line (blue line). Lower region is evaporation influenced (red area). To compare: Global Meteoric Water Line (GMWL $\delta^{2} \mathrm{H}=8 \delta^{18} \mathrm{O}+10$ ) and Rio Elqui water line (dotted) are added (see Strauch et al., 2006).

${ }^{2} \mathrm{H}$ and ${ }^{18} \mathrm{O}$ can be used to understand the origin and the interaction of river and groundwater within the watersheds.

The ${ }^{2} \mathrm{H}-{ }^{18} \mathrm{O}$ signature of both water catchments follow the meteoric water relation (Fig. 3) and point to precipitation controlled river waters originated under arid environment in the high Andes Mountain. For the mountain controlled Huasco catchment (Rio El Tránsito, Rio Del Carmen), the river water corresponds the run-off of the winter precipitation following the meteoric water relation. Evaporation processes along the river course affect the surface water shown by the smaller slope of the ${ }^{2} \mathrm{H}-{ }^{18} \mathrm{O}$ relation compared to the GMWL (Fig. 3).

Likewise, the deuterium excess $d$ decreases $<10 \%$ as consequence of dry and arid conditions. Those climatic conditions are responsible for the isotope variations at the high mountain glacier fields, the source region of the river run-off (see Stichler et al., 2001).

The groundwater signature at Vallenar correlates clearly with the river and dammed water of the Santa Juana reservoir located in the river basin upstream of Vallenar. Bank filtration from the river seems the main recharge process for the groundwater resource.

The Limarí catchment shows larger isotope variations due to the different catchments of the tributaries Rio Hurtado, Rio Grande with the region of Monte Patria, and Rio Limarí downstream of Ovalle. River water of both tributaries (Rio Hurtado, Rio Grande) corresponds to high altitude sources and fast transport downstream. Therefore, river water of both mountain tributaries keeps its meteoric origin down to the reservoirs as the ${ }^{2} \mathrm{H}^{-18} \mathrm{O}$ relation shows (Fig. 3). The lake water of the reservoirs Recoleta (Rio Hurtado) and La Paloma (Rio Grande) is clearly enriched in ${ }^{2} \mathrm{H}$ and ${ }^{18} \mathrm{O}$ in consequence of the dry climate in both watersheds. Similarly to the Huasco catchment, the isotopic signature of the groundwater at Monte Patria and Ovalle correlates significantly to the lake water of the dams. Therefore, it is assumed that groundwater is a mixture of base flow from the corresponding rivers and of bank filtrate from the reservoirs.

\section{Estimation of groundwater contribution in the Huasco and Limarí catchments}

To assess the water resources in the agricultural intensively used watersheds of Rio Huasco and Rio Limarí, the contribution of the surface and groundwater components has to be estimated. As shown above, the hydrochemical and isotope signatures of river water and groundwater distinguish in the different tributaries and groundwater abstraction wells of the both river catchments. Based on the knowledge available from the neighbouring Elqui catchment (Strauch et al., 2006), a first estimation of the ratio of subsurface flow (groundwater, base flow) and total flow (river water) in the groundwater exploration areas of Vallenar, Monte Patria, and Ovalle is reported. The water isotopes ${ }^{2} \mathrm{H} /{ }^{18} \mathrm{O}$ and, unlike the Elqui study, the electrical conductivity (EC) as a summary parameter of the hydrochemistry are used and combined with the hydrological balance equation applied by Kobayashi et al. (1999), Morche (2006) and Lehmann (2004) for hydrograph separation in mountain water catchments. There, the total flow within a catchment is the sum of surface flow or direct flow characterized by precipitation and rain events, and subsurface flow or base flow which corresponds to the groundwater component: 
Table 3. Contributions of groundwater to the total river flow in areas of groundwater abstraction.

\begin{tabular}{|c|c|c|c|c|}
\hline & \multicolumn{2}{|c|}{$\begin{array}{l}\delta^{18} \mathrm{O} \text { (in } \% \text { ) } \\
\delta^{18} \mathrm{O}_{\text {Precipitation }}=-15 \% \text {. } \\
\text { (Tapado glacier, Elqui Valley) } \\
\delta^{18} \mathrm{O}_{\text {River }}=\text { samples (No) } \\
\delta^{18} \mathrm{O}_{\text {Groundwater }}=\text { well water }(\mathrm{No})\end{array}$} & \multicolumn{2}{|c|}{$\begin{array}{l}\mathrm{EC}\left(\text { in } \mu \mathrm{S} \mathrm{cm}^{-1} \text { ) }\right. \\
\mathrm{EC}_{\text {Precipitation }}=200 \mu \mathrm{S} \mathrm{cm}^{-1} \\
\text { (mean precipitation La Serena, Elqui Valley) } \\
\mathrm{EC}_{\text {River }}=\text { samples (No) } \\
\mathrm{EC}_{\text {Groundwater }}=\text { well water (No) }\end{array}$} \\
\hline & $\begin{array}{l}\text { Direct flow }= \\
\text { Surface flow }\end{array}$ & $\begin{array}{l}\text { Base flow }= \\
\text { Groundwater }\end{array}$ & $\begin{array}{l}\text { Direct flow }= \\
\text { Surface flow }\end{array}$ & $\begin{array}{l}\text { Base flow }= \\
\text { Groundwater }\end{array}$ \\
\hline \multirow[t]{2}{*}{ Monte Patria } & \multicolumn{2}{|c|}{$\begin{array}{l}\delta^{18} \mathrm{O}_{\text {River }}:-11.91 \ldots-12.00(21,27) \\
\delta^{18} \mathrm{O}_{\text {Groundwater }}:-10.63(32)\end{array}$} & \multicolumn{2}{|c|}{$\begin{array}{l}\mathrm{EC}_{\text {River }}=287 \ldots 318(21,27) \\
\mathrm{EC}_{\text {Groundwater }}=631(32)\end{array}$} \\
\hline & $31 \%$ & $69 \%$ & $73-80 \%$ & $20-27 \%$ \\
\hline \multirow[t]{2}{*}{ Ovalle } & \multicolumn{2}{|c|}{$\begin{array}{l}\delta^{18} \mathrm{O}_{\text {River }}:-8.87(29) \\
\delta^{18} \mathrm{O}_{\text {Groundwater }}:-8.50(30)\end{array}$} & \multicolumn{2}{|c|}{$\begin{array}{l}\mathrm{EC}_{\text {River }}=464(33) \\
\mathrm{EC}_{\text {Groundwater }}=641(30)\end{array}$} \\
\hline & $6 \%$ & $94 \%$ & $40 \%$ & $60 \%$ \\
\hline \multirow[t]{2}{*}{ Vallenar } & \multicolumn{2}{|c|}{$\begin{array}{l}\delta^{18} \mathrm{O}_{\text {River }}:-11.91(1) \\
\delta^{18} \mathrm{O}_{\text {Groundwater }}:-11.80(15)\end{array}$} & \multicolumn{2}{|c|}{$\begin{array}{l}\mathrm{EC}_{\text {River }}=652(1) \\
\mathrm{EC}_{\text {Groundwater }}=895\end{array}$} \\
\hline & $4 \%$ & $96 \%$ & $35 \%$ & $65 \%$ \\
\hline
\end{tabular}

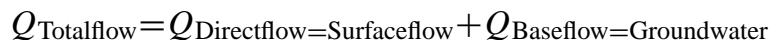

For the isotope balance follows

$\delta_{T} Q_{T}=\delta_{S} Q_{S}+\delta_{G} Q_{G}$

where the $\delta$ values stand for the isotope concentration.

Using the two-component isotope mixing model, the ratio of the subsurface/groundwater flow to the total flow follows after Eq. (2)

$Q_{G} / Q_{T}=\left(\delta_{\text {River }}-\delta_{\text {Precipitation }}\right) /\left(\delta_{\text {Groundwater }}-\delta_{\text {Precipitation }}\right)$.

Instead of isotopes EC values can also be used.

For the groundwater abstracting areas, measured data from the regions themselves and from the Elqui catchment are appropriated (see Table 3 ).

For the roughly estimation of the contribution of groundwater to the total river flow in the area of Vallenar, Monte Patria and Ovalle, the percentages are calculated after Eq. (3) as reported in Table 3. The parts of groundwater distinguish according to the parameters used.

In the Monte Patria region before the inflow to the La Paloma reservoir, groundwater contribution to the river water (discharge) is estimated in a range of $70 \%$ by ${ }^{18} \mathrm{O}$. For the regions of Vallenar and Ovalle, the groundwater and river water do not distinguish each other, but are enriched in ${ }^{18} \mathrm{O}$ relative to the mountain input. However, the interaction between groundwater and surface water controls the isotope signature which explains the high groundwater input of $>90 \%$ in the Vallenar and Ovalle region. The main aquifer in the surroundings of Vallenar is controlled by the Santa Juana reservoir, and the Rio Huasco function as a discharge drain for that aquifer (Rojas et al., 2008). Thus, the pollution of groundwater by anthropogenic activities could play an important role for the water quality in downstream areas, and for the water use there.

In contrast to the isotope parameter, the EC parameter reflect stronger the different mineralization of river and groundwater caused by geogenic and anthropogenic impacts. The higher mineralized river and groundwater particularly in the Vallenar and Ovalle regions is obviously caused by anthropogenic pollution affecting both compartments. This assumes a higher groundwater input up to $65 \%$. In Monte Patria, the groundwater input does not extend $27 \%$.

\section{Conclusions}

By means of a multi-parameter approach using hydrochemical and isotope methods, the water components of river catchments in semi-arid environment as surface water, subsurface and groundwater, and precipitations can be characterized due to their origin, interaction each other, and contamination.

For the Huasco and Limarí catchments, the river water corresponds clearly to the high mountain sources region fed by precipitation as shown by the ${ }^{2} \mathrm{H}$ and ${ }^{18} \mathrm{O}$ relation. The arid conditions within the catchments influence strongly the surface water by evaporation processes.

On the other hand, the groundwater formed by infiltration processes is considered as a mixture of river water, dammed water and partly water from fractured aquifers. However, because of the intensive agriculture in the lower part of the 
catchments groundwater is significantly affected by anthropogenic activities as the water quality shows.

Moreover, combining the hydrological water balance and the isotope mixing model, the interaction between groundwater and river water could be estimated. It can be concluded for the lower parts of both catchments that groundwater discharges from the shallow aquifers into the rivers.

Such multi-methodological studies can help to improve the knowledge about the surface and groundwater dynamic which is important for a sustainable water resource management in arid zones.

Acknowledgements. We thank the Chilean Water Authority (Dirección General de Aguas, Ministerio de Obras Públicas) for giving us river discharge data, and Aguas Chañar, Aguas del Valle, and the Junta de Vigilancia del Río Grande, Limarí y sus Afluentes (M. Muñoz) for helping us with well sampling, and the Universidad de La Serena and CEAZA for assisting us during the sampling campaign. Our technicians from the UFZ-Departments Hydrogeology, Analytical Chemistry and Isotope Hydrology, Mrs. S. Köhler, Mrs. P. Blümel, Mr. W. Staedter and Mr. J. Steffen are thanked for the analysis of the water samples, as well as D. López (CEAZA) for the preparation of Fig. 1. The Helmholtz Centre for Environmental Research UFZ kindly supported the pilot project.

Edited by: R. Garraud

Reviewed by: one anonymous referee

\section{References}

Bissig, T., Clark, A. H., Lee, J. K. W., and Hodgson, C. J.: Miocene landscape evolution and geomorphologic controls on epithermal processes in El Indio-Pascua $\mathrm{Au}-\mathrm{Ag}-\mathrm{Cu}$ belt, Chile and $\mathrm{Ar}-$ gentina, Econ. Geol. 7, 971-996, 2002.

CADE-IDEPE: Diagnostico y Clasificación de los Cursos y Cuerpos de Agua Según Objetivos de Calidad, Cuenca del Río Huasco, DGA - Dirección General de Aguas, 105 pp., 2004a.

CADE-IDEPE: Diagnostico y Clasificación de los Cursos y Cuerpos de Agua Según Objetivos de Calidad, Cuenca del Río Limarí, DGA - Dirección General de Aguas, 131 pp., 2004b.
DGA: Valores Sinopticus DCP, Rio Huasco, unpublished data, 2007.

Gehre, M. and Strauch, G.: High-temperature elemental analysis and pyrolysis techniques for stable isotope analysis, Rapid Commun. Mass Spectrom., 17, 1497-1503, 2003.

Kobayashi, D., Ishii, Y., and Kodama, Y.: Stream temperature, specific conductance and runoff process in mountain watersheds, Hydrol. Process., 13, 865-876, 1999.

Lehman, F.: Analysen zur Ganglinienseparation im Einzugsgebiet Spissibach, Summary Diploma Thesis by Weingartner, R. and Hunziker, J.: Berner Hydrograph, 19, 11-12, online available at: http://hydrant.unibe.ch/publi/hydrograph.html, August 2004.

Maksaev, V., Moscoso, R., Mpodozis, C., and Nassi, C.: Las unidades volcánicas y plutónicas del Cenozoico Superior en la alta cordillera del Norte Chico $\left(29^{\circ}-31^{\circ} \mathrm{S}\right)$ : geología, alteración hidrotermal y mineralización, Rev. Geol. Chile, 21, 11-51, 1984.

Morche, D.:Aktuelle hydrologische Untersuchungen am PartnachUrsprung (Wettersteingebirge), Oberbayern, Wasserwirtschaft, 1-2, 53-58, 2006.

Ribbe, L., Atenas, M., Kretschmer, N., Oyarzun, R., and Salgado, E.: Monitoring to Support Water Quality Management in NorthCentral Chile, Proceedings of the World Water Congress, OS1nWater quality 2, abs. 723, Montpellier, 2008.

Rojas, C., Riquelme, R., Herrera, C., and Bembow, M.: Dynamics, qulity and quantity of groundwater and surface water resources of the semiarid Huasco basin: a multidisciplinary approach, 4th Alexander von Humboldt International Confernce, Santiago de Chile, 24-28 November, 2008, Abstract volume, p. 73, online available at: http://meetings.copernicus.org/avh4/, 2008.

Stichler, W., Schotterer, U., Fröhlich, K., Ginot, P., Kull, C., Gäggeler, H., and Pouyaud, B.: Influence of sublimation on stable isotope records recovered from high-altitude glaciers in the tropical Andes, J. Geophys. Res., 106(D19), 22613-22620, 2001.

Strauch, G., Oyarzun, J., Fiebig, E. Gonzales, and Weise, S. M.: Contributions of the different water sources to the Elqui river (Northern Chile) runoff evaluated by H/O isotopes, Isotopes Environm. Health Studies, 42(3), 303-322, 2006. 